Logos Universality Mentality Education Novelty, Section: LAW

ISSN: $2284-5968$ (print), ISSN: $2284-5968$ (electronic)

Covered in: CEEOL, Index Copernicus, Ideas RePeC, EconPapers, Socionet

\title{
THE NECESSITY OF SETTING UP THE AD HOC INTERNATIONAL CRIMINAL TRIBUNALS. THE INTERNATIONAL CRIMINAL TRIBUNAL FOR THE FORMER YUGOSLAVIA: (1993-TODAY)
}

\section{Denisa $B A R B U$}

Doi: http://dx.doi.org/10.18662/lumenlaw.2015.0401.06

Logos Universality Mentality Education Novelty, Section: LAW, 2015, Volume IV, Issue 1, pp: 57-63

Published by:

Lumen Publishing House

On behalf of:

Lumen Research Center in Social and Humanistic Sciences 


\title{
The Necessity of Setting up the Ad Hoc International Criminal Tribunals. The International Criminal Tribunal for the Former Yugoslavia: (1993-today)
}

\author{
Denisa BARBU ${ }^{1}$
}

\begin{abstract}
This tribunal has been set up for the punishment of persons responsible for serious violations of international humanitarian law ${ }^{2}$ committed in the territory of the former Yugoslavia since 1991. The International Criminal Tribunal for the former Yugoslavia is a United Nations structure established for the prosecution of serious crimes committed during the wars in the former Yugoslavia. The Tribunal is an ad hoc court, which sits in Hague, Netherlands, and was established by resolution 827 of the Security Council of the United Nations, adopted on May 25, 1993 (Ackerman, O'Sullivan, 2000), as a measure to restore the international peace and security, adopted under Chapter VII of the Charter of the United Nations (Onica- Jarka, 2009, p. 107).
\end{abstract}

Keywords: the investigations, crimes, violations of the Geneva Conventions, jurisdictions.

1 Valahia University of Targoviste, Faculty of Law and Administrative Sciences, The Department of Administrative Sciences, denisa.barbu77@yahoo.com.

2 (See annex I); Denisa Barbu, Răspunderea persoanei fizice în dreptul international penal, Ed. Lumen, Iasi, 2015, pp.55-61.

Barbu, D. (2015). The Necessity of Setting up the Ad Hoc International Criminal Tribunals. The International Criminal Tribunal for the Former Yugoslavia: (1993-today). Logos Universality Mentality Education Novelty, Section: LAW, IV(1), 57-63. Doi: http://dx.doi.org/10.18662/lumenlaw.2015.0401.06 
This Court has material jurisdiction over four groups of crime committed on the territory of the former Yugoslavia: violations of the Geneva Conventions (article 2 in the Statute), violations of the laws or customs of war (article 3 in the Statute), genocide (article 4) and crimes against humanity (Aldrich, 1996, pp. 64-68).

The maximum penalty that can be imposed is life imprisonment (Bassioune, 1996), different States have signed agreements with the United Nations for the implementation of custodial punishment (17 States).

The final indictments were issued in December 2004; the last being confirmed in the spring of 2005 (Boelaert-Suominen, 2001, pp. 95-155), the Tribunal intending to complete all investigations by the end of 2012 (Cassese, 2004, pp. 585-597) and all appeals by 2015, unless Radovan Karadzic who is expected to be completed in 2014 (Ivkovic 1997, pp. 255267).

The Security Council of the United Nations has asked the Tribunal to complete the procedures until 31 December 2014, to prepare the transfer of responsibilities from the International Residual Mechanism for criminal courts which began operating for TPIFI branch from 1 July 2013. The International Criminal Tribunal for the former Yugoslavia (Robinson, 2000) will complete the investigations of the first court cases, including Radovan Karadzic, Ratko Mladic and Goran Hadzic will complete all the procedures on appeal lodged before 1 July 2013, any other notice for appeal submitted after this date will be managed by the International Residual Mechanism.

The International Criminal Tribunal for the former Yugoslavia is a party to the United Nations, being the first International Court of criminal justice, being considered a challenge, until November 1994, being presented and confirmed as the first indictment against Bosnian concentration camp commander (Kerr, 2000, pp. 17-26), the Serb Dragan Nikolic, the prosecutors pointing out that TPIFI is a viable Court. However, most of the new countries that were formed as a result of the break-up of RSFI especially Serbia and the Serbian entities in Bosnia Herzegovina, have refused to cooperate with this tribunal (Klip, Sluiter, 2003).

With regard to jurisdiction ratione personae, TPIFI Statute provides that it has jurisdiction over the individuals, guilty of serious breaches of international humanitarian law committed in the territory of the former Yugoslavia since 1991 (article 1, article 6 and article 7). They do not discuss anything about a certain property of persons, such as nationality or position occupied, intending to indict the persons responsible for the NATO attacks 
on Yugoslavia in 1999, the former heads of State and Government of NATO Member States. ${ }^{3}$

TPIFI published in 2004 a list of five successes: the shift from impunity to accountability, establishing the facts by gathering evidence, bringing victims to justice, stressing it with the large number of witnesses heard, the accomplishments in international law by concentrating some concepts of criminal international law, strengthening the rule of law, referring to the promotion of international standards in conducting the prosecution for war crimes (Köchler, 2003, pp. 166-184).

The Tribunal is made up of Chambers, the Registry and the Office of the Prosecutor (Lescure, 1996), with approximately 900 employees (Onica-Jarka, 2009, p. 114), some authors considered that the Assembly of States Parties is part of the structure of the Court.

The Prosecutor is responsible for investigating crimes, gathering evidence, being appointed by the UN Security Council, on the proposal of the UN Secretary General, first Prosecutor being Ramon Escovar Salom (1993-1994), then Carla Del Ponte (1997-2007), which until 2003 was the Prosecutor of the International Tribunal for Rwanda (Mc Donald, 2001, pp. 155-172).

The judges are 20 permanent and 3 ad litem serving on the Tribunal (Shenk, 1999, pp. 549-554), the Member States with observer status at the United Nations, they may propose up to two candidates of different nationalities at the Secretariat-General of the United Nations (Vierucci, 1995, pp. 134-143), passing the list to the UN Security Council, which selects 28-42 nominees by sending proposals to the UN General Assembly which elects 14 judges on this list. They have a mandate of 4-years. On October 19, 2011, Judge Theodor Meron (United States) was elected the new President of TPIFI in a special plenary session; and Carmel Agius (Malta) was elected Vice-Chairman (Robinson, 2000, pp. 569-589).

The registry is responsible for the Tribunal's administration, keeping the records, translation of documents, personnel management and procurement. It is also responsible for the detention unit for the defendants being held during the trial and to legal assistance program for those who do not allow their own defense.

It is currently headed by the Registrar John Hocking of Australia (since May 2009) (Tolbert, 2004, pp. 480-485).

${ }^{3}$ MacArthur S., Lanyers serve indictment on NATO leaders for war crimes, is listed at the internet address http://www.fantom-powa.net/Flame/lawyers-indict-nato.htm. 
In February, the Tribunal has indicted 161 people, completing the procedure regarding 97 of these: 17 being acquitted, 67 convicted, 13 persons have been transferred to the courts of Bosnia and Herzegovina (10), Croatia (2) and Serbia (1) (Meltraux, 2002, pp. 237-316). The defendants were among the soldiers, generals, police commanders, Prime Ministers; Slobodan Milosevic being the first head of State indicted for war crimes (Pilouras, 2002, p. 515-252). Other defendants of "high-level" were Milan Babic, former President of the Republic of Krajina, Haradinaj, former Prime Minister of Kosovo etc. (Roberts, 2002, pp. 623-663), Haradinaj was acquitted in April 2008, the first time, and after reopening the case he was acquitted a second time in 2012, 28 November.

Regarding the jurisdiction ratione temporis, the TPIFI Status indicates that it has jurisdiction for acts incriminated since 1991, so the judicial period remains open.

The difference between TPIFI and TIPR is that the first was set up in armed conflict (1993), without having a prediction regarding their completion, while the second was set up following the end of the internal armed conflict that has disturbed this country.

Competence ratione locii is limited to the territory in which, armed conflict for acts incriminated by the Statute, took place.

Criticisms regarding this International Court referred to the fact that it cannot operate while the war in the former Yugoslavia was still ongoing, Moscow criticizing this tribunal as being costly, inefficient and politically motivated. Slobodan Milosevic argued that it has no legal authority since it was established by the UN Security Council and not by the UN General Assembly.

Also, British euro-parliamentary Daniel Hannan has asked that this Court to be removed, whereas it is anti-democratic and in violation of national sovereignty (Ashley, 2005, p. 908-942).

As a response to critics, TPIFI proponents have responded in different publications that it promotes reconciliation, it does not fit into the political requirements desired by some that the Serbian aggression has been one of the most brutal, reflected in reality (Del Ponte, 2003, p. 76; Meron, 1994). 


\section{ANNEX 1}

\section{THE INTERNATIONAL CRIMINAL TRIBUNAL FOR THE FORMER YUGOSLAVIA}

\begin{tabular}{|c|c|c|}
\hline \multirow{6}{*}{$\begin{array}{l}161 \text { people } \\
\text { under } \\
\text { indictment }\end{array}$} & \multirow{5}{*}{124 completed processes } & -43 convictions \\
\hline & & -8 acquittals \\
\hline & & -25 exonerated from liability \\
\hline & & -4 transferred to national courts \\
\hline & & -6 dead during the process \\
\hline & 37 processes in progress & \\
\hline
\end{tabular}

\begin{tabular}{|l|}
\hline $\begin{array}{l}\text { Soldiers, generals, police commanders, politicians, heads of } \\
\text { Government, convicted persons in prison in Scheveninge, } 4 \mathbf{~ k m} \text { from } \\
\text { the Court }\end{array}$ \\
\hline 1. Slobodan Milosevic, died in prison on March 11,2006 \\
\hline 2. Radovan Karadzic, President of the Srpska Republic \\
\hline 3. Ratko Mladic, Bosnian Serb Commander \\
\hline 4. Croatian General Ante Gotovina \\
\hline 5. Dragan Vasiljkovic, Serbian Paramilitary \\
\hline 6. Naser Oric, Bosnian Army Commander \\
\hline 7. Stojan Zupljanin, Bosnian Serb Commander \\
\hline 8. Dragan Obrenovic, Bosnian Serb Commander \\
\hline 9. Milan Babic, Prime Minister of the Republic of Serbian Krajina \\
\hline 10. Ramush Haradinaj, Kosovo's Prime Minister \\
\hline 11. Biljana Plavsic, President of Srpska Republic \\
\hline 12. Zeljko Raznatovic "Arjan", Serbian Paramilitary Commander (assassinated \\
in 2000) \\
\hline 13. Vojislav Seselj, President of the Serbian Radical Party \\
\hline 14. Goran Hadzic, President of the Republic of Serbian Krajina \\
\hline 15. Milan Lukic, Commander of the Paramilitary Group the White Eagles \\
\hline
\end{tabular}




\section{REFERENCES}

Ackerman, J. E., \& O'Sullivan, E. (2000). Practice and procedure of the International Criminal Tribunal for the Former Yugoslavia: with selected materials for the International Criminal Tribunal for Rwanda. The Hague, KLI.

Aldrich, G. H. (1996). Jurisdiction of the International Criminal Tribunal for the Former Yugoslavia. American Journal of International Law, 64-68.

Ashley, W. R. (2005). Judging History: the History Record of the International Criminal Tribunal for the Former Yugoslavia. Human Rights Quarterly, 27(3), 908-942.

Barbu, D. (2015). Răspunderea persoanei fiæice in dreptul international penal. Iasi: Ed. Lumen.

Bassioune, M. C. (1996). The Law of the International Criminal Tribunal of the Former Yugoslavia. New York: Transnational Publications.

Boelaert-Suominen, S. (2001). The International Criminal Tribunal for the Former Yugoslavia (ICTY) year 1999: its place in the international legal system, mandate and most notable jurisprudence. Polish Yearbook of International Law, 95-155.

Cassese, A. (2004). The ICTY: A Living and Vital Reality. Journal of International Criminal Justice, 2(2), 585-597.

Del Ponte, C. (2003). The role of the International criminal prosecutions in reconstructing divided communities, public lecture by London School of Economics, (20 oct. 2003), p. 76.

Ivkovic, S. K. (1997). Justice by the International Criminal Tribunal for the Former Yugoslavia. Stamford Journal of International Law, 255-267.

Kerr, R. (2000). International Judicial Intervention: the International Criminal Tribunal for the Former Yugoslavia. International Relations, pp. 17-26.

Klip A., \& Sluiter, G. (2003). Annotated leading cases of international criminal tribunals, (vol. III), The International Criminal Tribunal for the Former Yugoslavia, 2000-2001. Schoten: Intersentia.

Köchler, H. (2003). Global Justice of Global Revenge?, International Criminal Justice then the Crossroads. Vienna/New York: Springer, pp. 166184.

Lescure, K. (1996). International Justice for Former Yugoslavia: the working of the International Criminal Tribunal of The Hague. The Hague.

Mc Donald, G. K. (2001). Reflections on the contributions of the 
International Criminal Tribunal for the Former Yugoslavia. Hastings International and Comparative Law Retrieved, pp. 155-172.

Meltraux, G. (2002). Crimes against humanity in the jurisprudence of the International Criminal Tribunal for the Former Yugoslavia and for Rwanda. Harvard International Law Journal, 237-316.

Meron, T. (1994). War Crimes in Yugoslavia and the Development of International Law. American Journal of International Law, American Society of International Law Issues, 88.

Onica-Jarka, B. (2009). Structuri de cooperare interguvernamentală institutionalizată. Bucharest: $\mathrm{CH}$ Beck Publishing House

Pilouras, S. (2002). The International Criminal Tribunal for the Former Yugoslavia and Milosevic's trial. New York Law School Journal of Human Rights, 515-252.

Roberts, K. (2002). The International Criminal Court, the law for the Former Yugoslavia. Leiden Court of International Law, pp. 623-663.

Robinson, L. R. (2000). Ensuring Fair and Expeditions International Criminal Trial sat the Tribunal for the Former Yugoslavia. European Journal of International Law, 11(3), Oxford University Press.

Robinson, P. L. (2000). Ensuring fair and expeditious trials at the International Criminal Tribunal for the Former Yugoslavia. European Journal of International Law, 569-589.

Shenk, M. D. (1999). International Criminal Tribunal for the Former Yugoslavia. The International Lawyer, 549-554.

Tolbert, D. (2004). Reflections on the ICTY Registry, Journal of International Criminal Justice, 2(2), 480-485.

Vierucci, L. (1995). The First Steps of the International Criminal Tribunal for the Former Yugoslavia. European Journal of International Law, 134- 